\title{
IN EASTERN EUROPE
}

ISSN 1392-6373 print / 2335-867X online

2018, 28 tomas, Nr. 5, p. 41-50

DOI: https://doi.org/10.5200/sm-hs.2018.057

\section{ELEKTROLITŲ BALANSO SUTRIKIMAI IR NEUROLOGINE PATOLOGIJA}

\author{
Liudmila Kimševaitè \\ Vilniaus miesto klinikinè ligoninè
}

\author{
Raktažodžiai: elektrolitų disbalansas, neurologinè pa- \\ tologija.
}

\section{Santrauka}

Darbo tikslas. Išanalizuoti neurologinę patologiją esant elektrolitų disbalansui.

Tyrimo medžiaga ir metodai. Vilniaus miesto klinikinès ligoninès Vidaus ligų, Nefrologijos skyriuose $2017 \mathrm{~m}$. birželi - $2018 \mathrm{~m}$. balandi tyrème 101 ligonị, kuriam buvo elektrolitų balanso sutrikimai ir neurologinè patologija. Ligonių amžius - 31-99 metai (vidurkis - 75,0 $\pm 1,3$ metų), moterų - 68, vyrų - 33 . Vidutinè stacionarinio gydymo trukmè - 10,5 dienos. Visiems ligoniams atliktas bendras ir biocheminis kraujo tyrimas, nustatyta elektrolitų koncentracija kraujo serume, atlikta elektrokardiograma, vidaus organų echoskopija, esant indikacijoms - galvos (stuburo) kompiuterinè tomografija, magnetinio rezonanso tomografija. Statistinių duomenų vidurkių skirtumai vertinti Stjudento (Student) patikimumo kriterijumi t. Skirtumai laikyti statistiškai patikimi esant $\mathrm{p}<0,05$.

Rezultatai. Išanalizuota neurologinè patologija esant elektrolitų disbalansui. Galvos smegenų kraujotakos sutrikimai buvo $26(25,7 \%)$ ligoniams, galvos smegenų edema - $1(1,0 \%)$, demencija - $6(5,9 \%)$, lètinè galvos smegenų išemija - 17(16,8\%), galvos smegenų augliai - 3(3,0\%), Parkinsono liga - 7(6,9\%), esencialinis tremoras - 2(2,0\%), epilepsija - 3(3,0\%), sinkope - 7(6,9\%), polineuropatija - 10(9,9\%), neuralgija - 5(5,0\%), raumenų spazmai - $9(8,9 \%)$, parestezijos - 2(2,0\%). Sergant ir išeminiu, ir hemoraginiu insultu nustatyti kalio, natrio ir chloro balanso sutrikimai. Vyravo hipokalemija. Galvos smegenų infarkto atveju kalio koncentracija kraujo serume buvo 3,28 \pm $0,2 \mathrm{mmol} / 1$, lètinès galvos smegenų išemijos atveju $-4,81 \pm 0,2 \mathrm{mmol} / \mathrm{l}(\mathrm{p}<0,001)$. Sergančiujų demencija natrio koncentracija kraujo serume buvo 125,5 \pm
2,2 mmol/l, lètinès galvos smegenų išemijos atveju $-138,76 \pm 1,3 \mathrm{mmol} / \mathrm{l}(\mathrm{p}<0,001)$. Galvos smegenų augliu sergantiems ligoniams nustatytas sumažėęs chloro kiekis kraujo serume - 93,83 $\pm 3,1 \mathrm{mmol} / \mathrm{l}$. Parkinsono liga sergantiems ligoniams vyravo hipokalcemija - 1,99 $\pm 0,1 \mathrm{mmol} / \mathrm{l}$. Epilepsijos atveju diagnozuota ir hipokalcemija $(1,92 \mathrm{mmol} / \mathrm{l})$, ir hiperkalcemija $(2,63 \mathrm{mmol} / \mathrm{l})$. Visoms migrena sergančioms ligonèms nustatyta padidejusi kalcio koncentracija kraujo serume - 2,66 $\pm 0,1 \mathrm{mmol} / \mathrm{l}$. Sinkopès atvejais stebèta ir hipokalemija $(3,09 \pm 0,2 \mathrm{mmol} / \mathrm{l})$, ir hiperkalemija $(5,80 \mathrm{mmol} / \mathrm{l})$. Esant parestezijoms nustatyta hipokalemija - 3,14 mmol/l. Ligonių, kuriems pasireiškè raumenų spazmai, kalcio koncentracija kraujo serume buvo $1,96 \pm 0,1 \mathrm{mmol} / \mathrm{l}$, magnio - 0,66 $\pm 0,01 \mathrm{mmol} / 1$.

Išvados. Kalio, natrio ir chloro balanso sutrikimai nustatyti sergant ir išeminiu, ir hemoraginiu insultu. Vyravo hipokalemija. Galvos smegenų infarkto atveju, palyginus su sergančiųjų lètine galvos smegenų išemija grupe, nustatytas statistiškai patikimas kalio koncentracijos kraujo serume sumažejjimas. Visiems Parkinsono liga sergantiems ligoniams nustatyti kalcio kiekio kraujo serume pokyčiai. Vyravo hipokalcemija. Epilepsinių priepuolių priežastimi gali būti ir hipokalcemija, ir hiperkalcemija. Hiperkalcemija gali provokuoti migreną. Kognityvinius sutrikimus nulèmé natrio kiekio pokyčiai. Visiems demencija sergantiems ligoniams nustatyta hiponatremija. Demencijos atveju, palyginus su sergančiujų lètine galvos smegenų išemija grupe, natrio koncentracijos sumažèjimas kraujo serume buvo statistiškai patikimas. Hiponatremija gali būti galvos smegenų edemos priežastis. Galvos smegenų augliu sergantiems ligoniams buvo hipochloremija. Sinkope gali ịvykti ir hipokalemijos, ir hiperkalemijos atveju. Hipokalemija gali sąlygoti parestezijas. Raumenų spazmai pasireiške esant hipokalcemijai ir hipomagnezemijai. 


\section{Ivadas}

Elektrolitų disbalansas (ED) ir osmoziniai pokyčiai yra viena dažniausių metabolinių neurologinių sutrikimų priežasčių [1]. Elektrolitų pokyčiai nulemia centrinès (CNS) ir periferinès nervų sistemos (PNS) pažeidimą - vangumą, raumenų silpnumą, traukulius, tetaniją. Neurologines manifestacijas dažniausiai sukelia natrio kiekio svyravimai. Natrio balanso sutrikimai iprasti sergant CNS ligomis. Jie pasireiškia ligonių gydymo eigoje ir gilina neurologinius simptomus. Nekoreguojama disnatremija didina ligoniu mirtingumą [2]. Hiponatremiją gali sukelti ligos ir patologinès būklès: hipovolemija, hipotiroidizmas, inkstų funkcijos nepakankamumas, antidiuretinio hormono sekrecijos sutrikimas, širdies nepakankamumas, kepenų cirozè, medikamentai. Neurologiniai hiponatremijos simptomai susiję su smegenų edema ir priklauso nuo natrio koncentracijos [3]. Jei smegenų edema nèra ryški ir užsitęsusi, koregavus natrio sutrikimus, smegenų funkcijos atsistato. Naujos neurologinès manifestacijos gali pasireikšti kaip osmozinio demielinizacijos sindromo rezultatas. Natrio balanso ir osmoliariškumo sutrikimai sukelia CNS slopinimą ir encefalopatiją, kalio balanso sutrikimai - PNS slopinimą ir raumenų silpnumą. Hiperkalcemija ir hipermagnezemija nulemia CNS ir PNS slopinimą, sukelia encefalopatiją ir arefleksinị raumenų silpnumą. Hipokalcemija ir hipomagnezemija sukelia CNS ir PNS dirginimą, klinikoje pasireiškiantị traukuliais, spazmais ir tetanija. Hipofosfatemijos ir hipomagnezemijos sukeltas raumenų silpnumas gali sutrikdyti kvėpavimo funkcijas. Traukuliai pasireiškia esant labai žemai natrio, magnio, kalcio ir fosforo koncentracijai. Magnio, fosforo ir kalcio pokyčiai gali sukelti jutimo sutrikimus [4, 5]. Hipofosfatemija sukelia encefalopatiją, miopatiją ir neuropatiją [6]. Išryškejjusi hipofosfatemija gali būti ūminio paralyžiaus (kvadriplegijos) priežastis [7]. Hipermagnezemijos atveju gali pasireikšti kvadriplegija ir kvėpavimo nepakankamumas, hiperkalcemijos atveju - centrinè tilto mielinozè, hipo- ar hiperkalemijos atvejais - širdies aritmijos. Hiperkalcemija dažna sergant onkologinèmis, neuroonkologinėmis ligomis. Šiems ligoniams pasireiškia ir hiponatremija, hipokalemija, hipomagnezemija, hipofosfatemija. Būtina tirti natrio, kalio, kalcio, magnio ir fosforo koncentraciją kraujo serume. Koreguojant $\mathrm{ED}$, galima išvengti neurometabolinių sindromų [8-10].

Darbo tikslas - išanalizuoti neurologinę patologiją esant elektrolitų disbalansui.

\section{Tyrimo medžiaga ir metodai}

Vilniaus miesto klinikinès ligoninès Vidaus ligų, Nefrologijos skyriuose $2017 \mathrm{~m}$. birželi - $2018 \mathrm{~m}$. balandị tyrème 101 ligoní, kuriam buvo elektrolitų balanso sutrikimai ir neurologinė patologija. Ligonių amžius - 31-99 metai (vidurkis - 75,0 $\pm 1,3$ metu). Vidutinè stacionarinio gydymo trukmè - 10,5 dienos. Visi ligoniai konsultuoti neurologo (straipsnio autorès). Jiems nustatyta neurologinè diagnozé, skirtas gydymas. Visiems ligoniams atliktas bendras ir biocheminis kraujo tyrimas, nustatyta elektrolitų koncentracija kraujo serume, atlikta elektrokardiograma, vidaus organu echoskopija, esant indikacijoms - galvos (stuburo) kompiuterinè tomografija (KT), magnetinio rezonanso tomografija (MRT). Statistinių duomenų vidurkių skirtumai vertinti Stjudento (Student) patikimumo kriterijumi t. Skirtumai laikyti statistiškai patikimi esant $p<0,05$.

\section{Rezultatai}

Galvos smegenų kraujotakos sutrikimai (GSKS) buvo 26(25,7 proc.) ligoniams: galvos smegenų infarktas (GSI) $-5(4,9$ proc.), GSI padariniai - 17(16,8 proc.), hemoraginis insultas (HI) - 3(3,0 proc.), HI padariniai - 1(1,0 proc.). Ir išeminio, ir hemoraginio insulto atveju nustatyti kalio, natrio ir chloro balanso sutrikimai. 4(3,9 proc.) iš 5(4,9 proc.) GSI sergančių ligonių buvo hipokalemija (vienam jų - ir hiponatremija - $124 \mathrm{mmol} / \mathrm{l}), 1(1,0$ proc.) ligoniui - hipochloremija $(95,4 \mathrm{mmol} / \mathrm{l})$. Kalio koncentracija kraujo serume sergant GSI buvo 3,28 $\pm 0,2 \mathrm{mmol} / \mathrm{l}$, LGSI atveju - 4,81 \pm $0,2 \mathrm{mmol} / 1$ ( $\mathrm{p}<0,001)$. $2(2,0$ proc.) iš $3(3,0$ proc.) HI sergančių ligonių nustatyta hipokalemija $(3,31 \mathrm{mmol} / \mathrm{l}), 1 \mathrm{jų} \mathrm{-} \mathrm{ir}$ hipochloremija (96,8 mmol/l). 1(1,0 proc.) HI patyrusiam ligoniui buvo hiponatremija $(129 \mathrm{mmol} / \mathrm{l})$.

Ligonė V.G., 85 metų, hospitalizuota bendros sunkios būklès. Serga KŠL, PV, prieš 6 metus patyrè išeminį insultą. Objektyviai: AKS-110/70 mmHg, P-100 k./min. Neurologinis tyrimas: platesnis dešinės akies vokų plyšys, ị skausmą reakcija išlikusi, sausgysliniai refleksai $\mathrm{s}>\mathrm{d}$, kairè hemiparezè, provokuojasi Babinskio refleksas kaireje. Tyrimai: leuk. $-9,55 \cdot 10^{9} / 1$, eritr.-3,83 $\cdot 10^{12} / 1$, Hb- $102 \mathrm{~g} / 1$, tromb.$275 \cdot 10^{9} / 1$, gliuk.-5,35 mmol/1, K-2,73 mmol/1, Na-140 mmol/l. EKG: PV, tachisistolinė forma, KSH. Krūtinès ląstos rentgenografija: fibroziniai pakitimai plaučiuose. Galvos KT: (1 pav.). Diagnozè: KS̆L. Stabili KA, Fkl.III, ŠN C. Permanentinis PV, tachisistolinè forma. Hipokalemija. Galvos smegenų infarktas $A C M$ dex. baseine: kairẻ hemiparezè. Gydymas: infuzoterapija, oksigenoterapija, heparinas, eufilinas, mildronatas, digoksinas, furozemidas.

Galvos smegenų edema (GSE) pasireiškè 1(1,0 proc.) ligoniui. Ligonis I.L., 62 metų, hospitalizuotas skubos tvarka dèl dusulio, didelio bendro silpnumo, galvos sunkumo, svaigimo. Serga KŠL, PV. Objektyviai: AKS-120/80 mmHg, P-70 k./min., KD- 27 k./min. Būklè sunki, širdies ribos prasiplètusios ị abi puses, II tono akcentas, I tonas susilpnėjęs, kojose edemos. Neurologinis tyrimas: soporas, akių obuoliu 
judesiai ,plaukiojantys“, viršantakiniai, junginès, ragenos refleksai ryškiai susilpnèję $\mathrm{s}=\mathrm{d}$, reakcija ị skausmą vangi, difuzinè raumenų atonija, sausgyslinè arefleksija, patologinių refleksų neišgauta. Tyrimai: leuk.-9,46 $10^{9} / 1$, eritr.4,64 $10^{12} / 1, \mathrm{Hb}-145 \mathrm{~g} / \mathrm{l}$, hematokr.-40,5\%, tromb.-322 $\cdot 10^{9} / 1$, SPA-39\%, INR-1,6, gliuk.-7,54 mmol/1, Cl-76,1 mmol/1, $\mathrm{Mg}-0,82 \mathrm{mmol} / \mathrm{l}, \mathrm{K}-4,39 \mathrm{mmol} / 1, \mathrm{Na}-120 \mathrm{mmol} / \mathrm{l}$, troponinas $\mathrm{T}<50$ ng/l. EKG: EKS ritmas, ŠSD-69 k./min. Krūtinès ląstos rentgenografija: fibroziniai pakitimai plaučiuose, KMP, aortos dilatacija ir sklerozè. Galvos KT: (2 pav.). Diagnozè: dilatacinė kardiomiopatija. Ūminis širdies ir kraujagysliu nepakankamumas. Permanentinis PV, tachisistolinė forma, EKS implantavimas (2017). Hiponatremija, hipochloremija. Besiformuojanti galvos smegenų edema. Gydymas: oksigenoterapija, metaprololis, digoksinas, rivaroksabanas, torazemidas, furozemidas, pananginas, mildronatas, eufilinas, deksametazonas, Ringerio tirpalas, natrio hidrokarbonato tirpalas.

Demencija diagnozuota $6(5,9$ proc.) ligoniams. Jiems nustatyta hiponatremija. Demencijos atveju natrio koncentracija kraujo serume buvo 125,5 $\pm 2,2 \mathrm{mmol} / \mathrm{l}, \mathrm{LGSI}$ atveju $-138,76 \pm 1,3 \mathrm{mmol} / \mathrm{l}(\mathrm{p}<0,001)$.

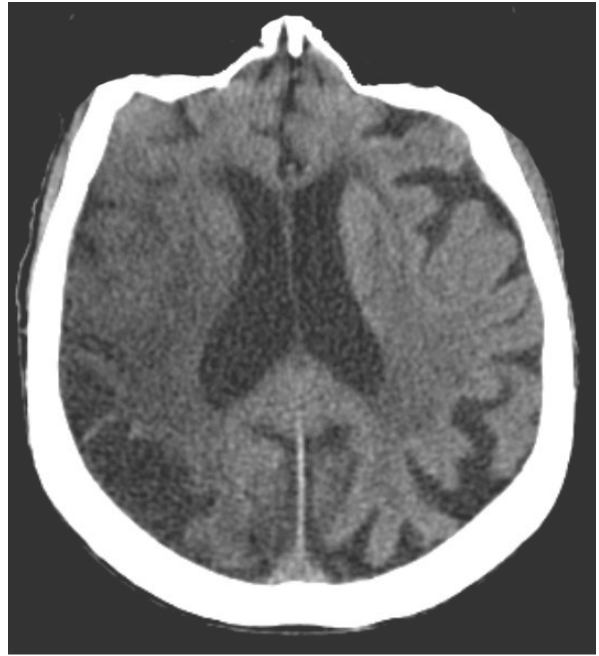

1 pav. Ligonès V.G. galvos KT: plati sumažinto tankio zona dešinio pusrutulio visose skiltyse; kraujagyslinės leukoencefalopatijos požymiai.

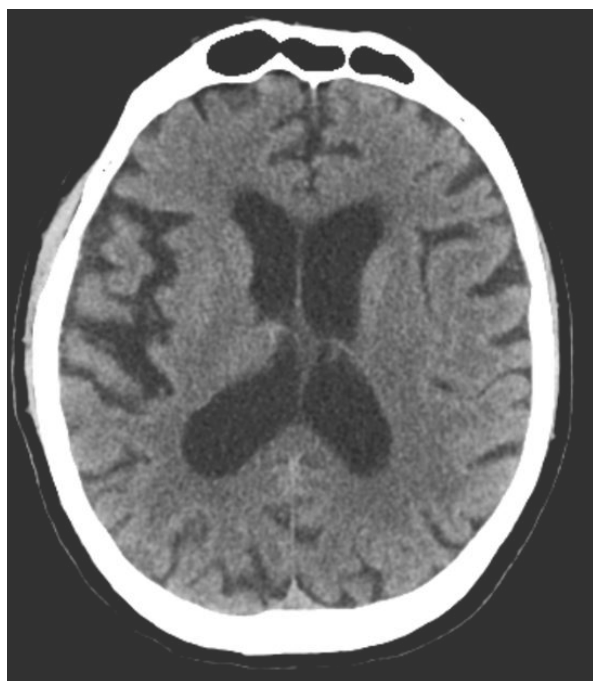

2 pav. Ligonio I.L. galvos KT: šoniniai skilveliai prasiplètę; subarachnoidiniai tarpai konveksitaliai prasiplètę, diferencijuoti; kraujagyslinès leukoencefalopatijos požymiai.
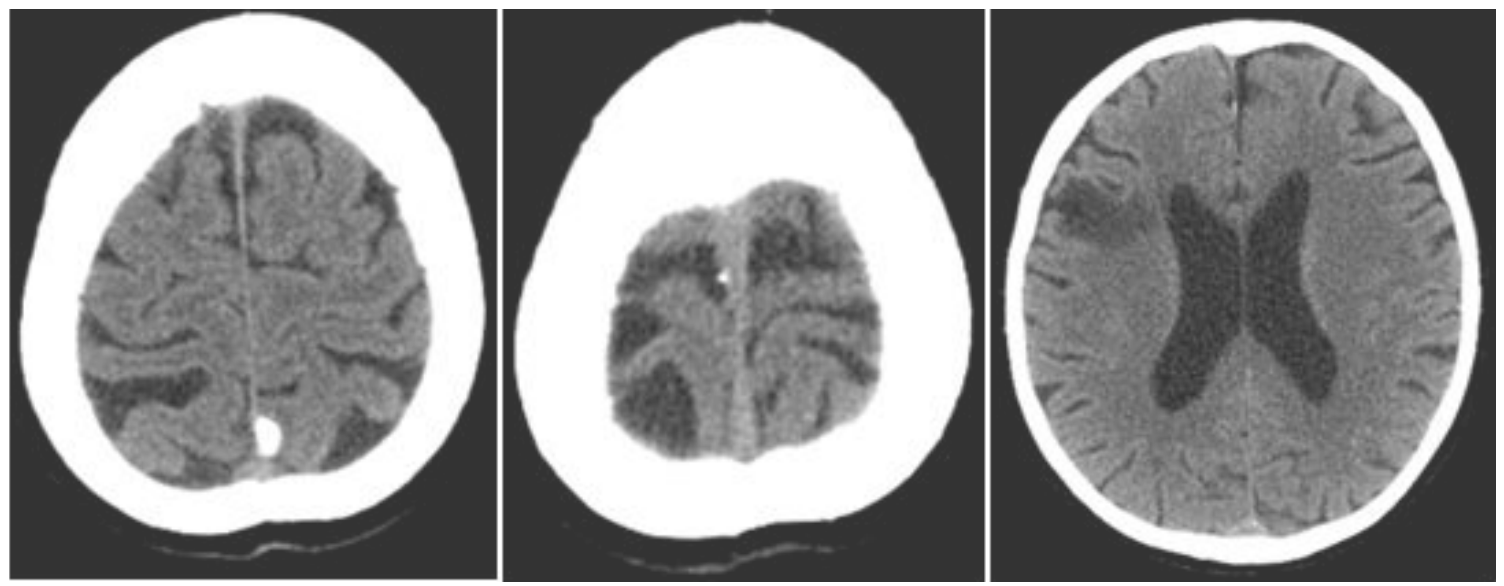

3 pav. Ligonès E.P. galvos KT: meningiomos kairèje parietalinejje ir dešinèje frontotemporalinèje srityse; dešinèje frontalinèje skiltyje netolygi hipodensinė zona, apimanti žievę ir požievị; lètinė kraujagyslinè encefalopatija. 
Lètinè galvos smegenų išemija (LGSI) buvo 17(16,8 proc.) ligonių.

Galvos smegenų augliai (GSA) diagnozuoti 3(3,0 proc.) ligoniams. Jiems nustatyta hipochloremija. Chloro koncentracija kraujo serume - 93,83 $\pm 3,1 \mathrm{mmol} / \mathrm{l}$.

Ligonè E.P., 74 metų, skundèsi galvos skausmu, svaigimu, pykinimu, vėmimu. Serga PAH, LIL, praeityje patyre išemini insultą. Diagnozuotos meningiomos, tačiau neoperuotos. Objektyviai: AKS-156/78 mmHg, P-68 k./min. Nueurologinis tyrimas: konvergencijos silpnumas dešine akimi, hipestezija kairèse galūnėse, nežymūs statinès ataksijos reiškiniai, sausgysliniai refleksai $\mathrm{s}>\mathrm{d}$, provokuojasi Babinskio refleksas kairèje, Marinesku-Radovičiaus refleksas. Tyrimai: leuk.-6,66 $10^{9} / 1$, eritr.-4,74 $10^{12} / 1, \mathrm{Hb}-138 \mathrm{~g} / 1$, tromb.-181 $10 \% / 1$, SPA-74\%, INR-1,2, gliuk.-5,76 mmol/1, bendr.balt.-63,8 g/l, Cl-93,1 mmol/1, K-3,8 mmol/1, Na-132 mmol/l. Šlapimo tyrimas: balt.-0,75 g/l. EKG: sinusinè bradikardija, I AV blokada, KSH. Kaklo kraujagyslių echoskopija: abiejų vidinių miego arterijų stenozé $<50$ proc., abiejų slankstelinių arterijų kilpos. Okulistas: hipertenzinè retinopatija $\mathrm{I}^{\circ}$, glaukoma $\mathrm{I}^{\circ}$. Psichiatras: nerimastingo tipo asmenybė, nepatikslintas nerimo sutrikimas. Galvos KT: (3 pav.). Diagnozè: hipertenzinè kardiopatija $\mathrm{II}^{\circ}$, labai didelès rizikos grupè, ir nefropatija. LIL, II stadija. Hipochloremija, hiponatremija. Meningiomos. Išeminio insulto padariniai $A C M$ dex. baseine: kairysis hemisindromas. Gydymas: eufilinas, klopidogrelis, lerkanidipinas, moksonidinas, olmesartanas, torazemidas, sertralinas.

Parkinsono liga (PL) sirgo 7(6,9 proc.) ligoniai. Visiems ligoniams nustatyti kalcio kiekio kraujo serume pokyčiai: $6(5,9$ proc.) ligoniams buvo hipokalcemija (kalcio koncentracija kraujo serume - 1,99 $\pm 0,1 \mathrm{mmol} / \mathrm{l}), 1$ (1,0 proc.) - hiperkalcemija $(2,84 \mathrm{mmol} / \mathrm{l})$.

Esencialinis tremoras (ET) diagnozuotas 2(2,0 proc.) ligoniams. Jiems buvo kalio ir natrio balanso sutrikimai hipokalcemija $(1,97 \mathrm{mmol} / \mathrm{l})$ ir hiponatremija $(132 \mathrm{mmol} / \mathrm{l})$.

Epilepsija sirgo 3(3,0 proc.) ligoniai: 2 ligoniams nustatyta hipokalcemija (kalcio koncentracija kraujo serume - 1,92 mmol/l), 1 - hiperkalcemija (2,63 mmol/l).

Ligonè N.M., 65 metur, skundèsi galvos skausmu, nemiga. Prieš savaitę įvyko epilepsijos priepuolis. Epilepsija diagnozuota prieš 20 metų, vartoja okskarbazepiną. Serga PAH, obstrukciniu bronchitu. Objektyviai: AKS- 210/120 $\mathrm{mmHg}, \mathrm{P}-88 \mathrm{k} . / \mathrm{min}$. Neurologinis tyrimas: horizontalus abipusis nistagmoidas, sausgysliniai refleksai aukšti $\mathrm{s}=\mathrm{d}$, su išplèstomis refleksogeninèmis zonomis, ryški vegetatika, funkcinès reakcijos. Tyrimai: leuk.- $6,07 \cdot 10^{9} / 1$, eritr.$4,34 \cdot 10^{12} / \mathrm{l}, \mathrm{Hb}-130 \mathrm{~g} / \mathrm{l}$, tromb.-249 $10^{9} / \mathrm{l}$, gliuk. $-5,3 \mathrm{mmol} / \mathrm{l}$, Cl-92,5 mmol/1, Ca-2,02 mmol/1, K-4,52mmol/1, Na-124 $\mathrm{mmol} / \mathrm{l}$. EKG: be patologijos. Krūtinès ląstos rentgenogra- fija: fibroziniai pakitimai plaučiuose. Spirometrija: galima $I^{\circ}$ plaučių restrikcija. Okulistas: I-II ${ }^{\circ}$ retinopatija, prasidedanti katarakta. Diagnozè: hipertenzinè širdies liga, AKS II ${ }^{\circ}$ padidejjimas, didelè rizikos grupè. Hipertenzinè krizè. Hipertenzinè I-II ${ }^{\circ}$ retinopatija. Obstrukcinis bronchitas. Epilepsija, generalizuoti toniniai-kloniniai traukulių priepuoliai. Hipokalcemija, hiponatremija, hipochloremija. Gydymas: nebivololis, moksonidinas, perindoprilis, furozemidas, salbutamolis, okskarbazepinas, diazepamas, magnio preparatai. Kadangi okskarbazepinas gali sąlygoti hiponatremiją, ligone pasiųsta į Neurologijos skyrių antiepilepsinio gydymo korekcijai.

Migrena pasireiškè 3(3,0 proc.) ligonėms. Joms nustatyta hiperkalcemija. Kalcio koncentracija kraujo serume - 2,66 $\pm 0,1 \mathrm{mmol} / \mathrm{l}$.

Sinkope ịvyko 7(6,9 proc.) ligoniams. 6 (5,9 proc.) ligoniams diagnozuota hipokalemija (kalio koncentracija kraujo serume - 3,09 $\pm 0,2 \mathrm{mmol} / \mathrm{l}), 1$ (1,0 proc.) - hiperkalemija $(5,80 \mathrm{mmol} / \mathrm{l})$.

Polineuropatija buvo 10(9,9 proc.) ligonių. Jiems nustatytas kalio, kalcio ir chloro disbalansas. Vyravo hiperkalemija $-5,92 \pm 1,1 \mathrm{mmol} / \mathrm{l}$.

Neuralgija diagnozuota 5(5,0 proc.) ligoniams. 2 ligoniams buvo hipokalemija (kalio koncentracija kraujo serume - 3,37 mmol/l), 2 - hiperkalemija $(6,26 \mathrm{mmol} / \mathrm{l}) .1$ ligoniui buvo sumažejusi natrio koncentracija kraujo serume (129 $\mathrm{mmol} / \mathrm{l})$.

Raumenų spazmai vargino 9(8,9 proc.) ligonius. Visiems ligoniams nustatyti kalcio ir magnio kiekio kraujo serume pokyčiai - hipokalcemija ir hipomagnezemija. Kalcio koncentracija kraujo serume buvo $1,96 \pm 0,1 \mathrm{mmol} / \mathrm{l}$, magnio - 0,66 $\pm 0,01 \mathrm{mmol} / \mathrm{l}$.

Ligonè A.K., 71 metų, skundèsi širdies plakimu, kojų skausmu. Serga KŠL, PV. Objektyviai: AKS-120/70 mmHg, P-80 k./min., širdies veikla aritmiška. Neurologinis tyrimas: jutimo sutrikimų nèra, sausgysliniai refleksai kojose aukštoki $\mathrm{s}=\mathrm{d}$, kojų raumenų spazmai. Tyrimai: leuk.- $8,12 \cdot 10^{9} / 1$, eritr.5,28 $10^{12} / 1$, Hb-164 g/l, tromb.-200 $\cdot 10^{9} / 1$, D-dimerai - 2,99 $\mu \mathrm{g} / \mathrm{ml}$, gliuk. $-5,57 \mathrm{mmol} / \mathrm{l}, \mathrm{Ca}-1,92 \mathrm{mmol} / \mathrm{l}, \mathrm{P}-1,18 \mathrm{mmol} / \mathrm{l}$, Mg-0,64 mmol/l, K-3,92 mmol/1, Na-140 mmol/l. EKG: $\mathrm{PV}$, normosistolinè forma. Krūtinès ląstos rentgenografija: plaučiuose infiltracinių, židininių pakitimų nematyti, aortos sklerozè. Diagnozė: KŠL. Lètinis PV. Hipomagnezemija, hipokalcemija. Raumenų spazmai. Gydymas: izosorbido mononitratas, digoksinas, pananginas, magnio citratas, kalcio preparatai, neurorubinas.

Parestezijos buvo 2(2,0 proc.) ligoniams. Jiems nustatyta hipokalemija (kalio koncentracija kraujo serume - 3,14 $\mathrm{mmol} / \mathrm{l})$.

Ligonis L.A., 49 metų, skundèsi rankų tirpimu. Serga 
PAH. Objektyviai: AKS-160/100 mmHg, P-76 k./min. Neurologinis tyrimas: parestezijos rankose, sausgysliniai refleksai $\mathrm{s}=\mathrm{d}$, patologinių refleksų neišgauta, paravertebriniai taškai nèra skausmingi. Tyrimai: leuk.-7,48 $10^{9} / 1$, eritr.-4,21 $10^{12} / 1, \mathrm{Hb}-115 \mathrm{~g} / 1$, tromb.- $191 \cdot 10^{9} / 1$, šlapalas-5,6 $\mathrm{mmol} / \mathrm{l}$, kreatinin.-82 $\mu \mathrm{mol} / \mathrm{l}$, GFG- $84 \mathrm{ml} / \mathrm{min} . / 1,72 \mathrm{~m}^{2}$ ), gliuk.-5,1 mmol/1, Cl-98,6 mmol/1, K-3,12 mmol/1, Na-140 mmol/l. EKG: KSH požymiai. Krūtinès ląstos rentgenografija: fibroziniai pakitimai plaučiuose. Vidaus organų echoskopija: be patologijos. Diagnozė: hipertenzinè širdies liga, AKS II ${ }^{\circ}$ padidejjimas, didelè rizikos grupè. Hipokalemija. Parestezijos. Gydymas: nebivololis, doksazosinas, rilmenidinas, kalio chlorido ir natrio chlorido infuzijos, benfotiaminas.

\section{Rezultatų aptarimas}

Elekrolitų balanso sutrikimai tirti 110 insultu sergančių ligonių: 55 jų sirgo išeminiu insultu, 55 - hemoraginiu. Tirta natrio, kalio ir chloro koncentracija kraujo serume. $29(52,72 \%)$ hemoraginiu insultu sergantiems ligoniams buvo disnatremija: 23(41,8\%) jų nustatyta hiponatremija, $6(10,9 \%)$ - hipernatremija. Natrio balanso sutrikimai pasireiškè 23(41,8\%) išeminiu insultu sergantiems ligoniams: $21(38 \%)$ jų nustatyta hiponatremija. Vidutinè natrio, kalio, chloro koncentracija hemoraginio insulto atveju buvo atitinkamai $136,18 \pm 10,5,3,83 \pm 0,65,97,96 \pm 16,74 \mathrm{mmol} / 1$, išeminio insulto atveju - $135,08 \pm 9,08,4,00 \pm 0,75,100,27 \pm 8,39$ $\mathrm{mmol} / 1$. Kalio kiekio pokyčiai buvo $21(38,18 \%)$ hemoraginiu insultu sergančiam ligoniui, $19(34,55 \%)$ jų nustatyta hipokalemija, 2(3,63\%) - hiperkalemija. Išeminio insulto atveju 15(27,22\%) ligonių buvo diskalemija, 12(21,81\%) jų nustatyta hipokalemija ir 3(5,45\%) - hiperkalemija. Chloridu kiekis buvo sutrikęs $33(60 \%)$ hemoraginiu insultu sergantiems ligoniams, 20(36,4\%) jų nustatyta hipochloremija, $13(23 \%)$ - hiperchloremija. Išeminio insulto atveju 40(60\%) ligonių buvo chloro kiekio sutrikimų, iš jų 33(40\%) nustatyta hipochloremija, 18(32,7\%) - hiperchloremija. Sergant ir hemoraginiu, ir išeminiu insultu stebimi natrio, kalio ir chloro balanso sutrikimai - vyravo hiponatremija, hipokalemija ir hipochloremija [11]. Serumo natrio ir kalio koncentracija buvo nustatoma 196 ligoniams, sergantiems ūminiu išeminiu insultu ir 56 ligoniams, sergantiems cerebrine kraujosruva. Hipernatremija, hiponatremija, hiperkalemija ir hipokalemija buvo didesnè esant kraujosruvai $(18 \%, 7 \%, 13 \%$ ir $14 \%$ atitinkamai) negu infarktui $(4,5 \% ; 4,5 \% ; 11 \%$ ir $6 \%$ atitinkamai). Smegenų infarkto atveju hipernatremija ir hiponatremija buvo didesnè esant kortikiniam pažeidimui. Cerebrinès kraujosruvos atveju hipernatremija buvo didesnè esant smegenų kamieno pažeidimui. Hipernatremija 27\% atvejų buvo esant didelei hematomai, $16 \%$ - vidutinei ir $1 \%$ - mažai. Panašios tendencijos buvo ir hiponatremijos ir hi- perkalemijos atvejais. Vyresniems ligoniams ED buvo labiau didesnis negu jauno ir vidutinio amžiaus ligoniams. IFN ir CD buvo dažniausios sergančiujų insultu su hipernatremija komplikacijos (42\% ir 32\% atitinkamai), kurių 57\% mire per vieną mènesị nuo hospitalizacijos [12]. Hiponatremija yra insulto ir kardiovaskulinès ligos rizikos veiksnys. Net nežymi hiponatremija yra susijusi su padidejusiu mirtingumu 30 dienų laikotarpiu po MI. Neseniai ịrodytas padidèjęs mirtingumas 3 metų laikotarpiu po insulto. Tirti 3585 ligoniai, sergantys ūminiu išeminiu insultu. Hiponatremija nustatyta 565 (16\%) ligoniu. Hiponatremija buvo susijusi su didesniu mirtingumu ligoninèje ir praejus 3 ir 12 mènesių po išeminio insulto [13]. Tirta 8540 ligonių (47,4\% vyrų, amžiaus vidurkis $77,3 \pm 12,0$ metų). Hipernatremija nustatyta 3,3\% ligonių, hiponatremija - 13,8\% ligonių. Hiponatremija dominuoja sergant ūminiu išeminiu insultu ir yra susijusi su jaunesnių kaip 75 metų amžiaus ligonių mirtingumu [14]. Tirta 3314 ligonių. Analizuotas hipochloremijos ir hiponatremijos poveikis mirtingumui sergantiems ūminiu išeminiu insultu. Hospitalizacijos metu ligoninejje mirè 118 (3,6\%) ligonių. Nustatyta, kad hipochloremija susijusi su stacionarinių ūminiu išeminiu insultu sergančių ligonių mirtingumu. Hipochloremija mirtingumą didino 2,43 karto. Hiponatremijos ir hospitalinio mirtingumo ryšio nenustatyta [15]. Analizuota 100 išeminiu insultu sergančių ligonių vandens sudètis, jo pasiskirstymas organizme. Tirta natrio ir kalio koncentracija plazmoje, eritrocituose ir kūno ertmèse. Nustatyta, kad dažniausias vandens-elektrolitų balanso sutrikimas ūminiu išeminio insulto periodu yra intraląstelinė ar generalizuota hidratacija (81\%). Parenchiminès-subarachnoidinès kraujosruvos atveju generalizuota dehidratacija yra kombinuota su ekstraląstelinio tarpo hiperhidratacija. Išeminio insulto atveju anhidremija būna iki 10 - 18 dienų. Elektrolitų metabolizmo pokyčiai vyksta sumažèjus natrio ir kalio koncentracijai intraląsteliniame lygyje - kalio netenkama vidutiniškai $29 \%$, natrio - 15,5\% [16]. Tirtas hiperchloremijos poveikis klinikinèms baigtims esant intracerebrinei kraujosruvai. Tirta 219 ligonių (143 su vidutine hiperchloremija, 76 - be hiperchloremijos) ir 100 kontrolinès grupès asmenų. Hospitalinis mirtingumas buvo didesnis esant hiperchloremijai (34\% ir $14 \%, p=0,02$ ) [17]. Hiperchloremija susijusi su ūminiu IFN ligoniams, sergantiems subarachnoidine kraujosruva (SAK). Tirta 1267 ligoniai, 16,7\% jų pasireiškè ūmus IFN. Palyginus su ligoniais be IFN, ligoniams su IFN dažniau pasireiškia CD (atitinkamai 21,2\% ir 9,8\%; $<<0,001$ ), hipertenzija $(70,3 \%$ ir $50,5 \% ; \mathrm{p}<0,001)$, jų kreatinino kiekis didesnis. Ligoniams su ūminiu IFN buvo didesnis serumo chloridų ir natrio kiekis (atitinkamai 113,4 $\pm 0,6 \mathrm{mmol} / \mathrm{l}$ ir 107,1 $\pm 0,2$ $\mathrm{mmol} / 1,143,3 \pm 0,4 \mathrm{mmol} / 1$ ir $138,8 \pm 0,1 \mathrm{mmol} / 1, \mathrm{p}<0,001)$. Ligonių su ūminiu IFN buvo didesnis mirtingumas $(28,3 \%$ 
ir $6,1 \%, \mathrm{p}<0,001)$. Serumo chloridų koncentracijos padidèjimas buvo susijęs su ūminiu IFN pasireiškimu. Sunkiems ligoniams su SAK nustatytas hiperchloremijos ir ūmaus IFN ryšys, ūminio IFN ir mirtingumo ryšys [18]. Atlikta ED esant talaminei kraujosruvai klinikine analizè. 67 ligoniams KT diagnozuota talamine kraujosruva ir 256 ligoniams - netalaminè kraujosruva. Elektrolitai šiems ligoniams tirti per 24 valandas nuo hospitalizacijos. Serumo kalio kiekis buvo pakitęs 37,31\% ligonių su talamine kraujosruva ir 24, 21\% ligonių su netalamine kraujosruva. Kalio, natrio ir chloro kiekis buvo pakitęs ligoniams su talamine, pamato branduolių ir skiltine kraujosruva. Ligonių su talamine kraujosruva ir ED mirtingumas buvo didesnis, palyginus su ligoniais, kurių elektrolitų kiekis buvo nepakitęs. ED gali turèti įtakos didesniam mirtingumui ligoniams su talamine kraujosruva [19]. Daugelio studijų duomenimis, SAK susijusi su hiponatremija. SAK ir kalio kiekio ryšys yra mažiau studijuotas. Tirta 114 ligonių su SAK. Natrio ir kalio kiekis tirtas praejus 14 dienų po SAK. Po SAK stebima ir hipokalemija, ir hiponatremija. Hipokalemija yra dažnesnė [20]. Hipokalemija yra nepalankios kardiovaskulinès ir renalinès baigties veiksnys. Tirtas ryšys tarp serumo kalio kiekio ir ūminio išeminio insulto baigčių. Ligoniai suskirstyti ị dvi grupes: hipokalemija $(\mathrm{K}<3,5 \mathrm{mmol} / \mathrm{l})$ ir normokalemija $(3,5 \mathrm{mmol} / \mathrm{l}$ $\leq \mathrm{K} \leq 5,5 \mathrm{mmol} / \mathrm{l})$. Ligoniu procentas su bloga baigtimi praèjus trims ménesiams po ūminio išeminio insulto buvo didesnis hipokalemijos grupeje $(45,5 \%)$. Hipokalemija susijusi su bloga prognoze praejus trims mènesiams po pirmąkart ịvykusio ūminio išeminio insulto [21]. Pateiktas neaiškios priežasties ryškios hipokalemijos klinikinis atvejis ligoniui, gydomam dèl SAK [ 22]. Mūsų tyrimo duomenimis, ir GSI ir HI patyrusiems ligoniams nustatyti kalio, natrio ir chloro balanso sutrikimai. Vyravo hipokalemija. GSI atveju kalio koncentracija kraujo serume - 3,28 $\pm 0,2 \mathrm{mmol} / \mathrm{l}$, HI atveju $3,31 \mathrm{mmol} / \mathrm{l}$.

Hiponatremija yra dažnas elektrolitų balanso sutrikimas. Simptomų sunkumas priklauso nuo bendros būklès ir smegenų edemos laipsnio, kuri yra sumažejusio natrio kiekio kraujo serume rezultatas. Žaibiška hiponatremija gali sąlygoti staigų smegenų edemos atsiradimą. Sunki ūminè hiponatremija yra gyvybei pavojinga būklè: 38 metų moteris mirè nuo galvos smegenų edemos, kurios priežastis buvo ūminè izovoleminè hiponatremija [23]. Daugumoje atvejų hiponatremija yra susijusi su hipotoniškumu (mažu osmoziniu slègiu), kuris nulemia vandens judèjimą ị smegenis. Hiponatremijos korekcija dažnai nepašalina mielinolizès rizikos. Neurologinių sutrikimų atvejais euvoleminè hiponatremija (paprastai sąlygoja antidiuretinio hormono sekrecijos sindromą) gali skatinti hipovoleminę cerebral salt wasting būklę [24]. Hiponatremija su cerebriniais simptomais yra sunki ligonio būklè, reikalaujanti skubios pagalbos (deguonies terapija, kvėpavimo ir kraujotakos funkcijų gerinimas). Reikia vengti perkorekcijos, mažinti osmozinès demielinizacijos riziką (natrio koncentracijos kraujo serume seka, diurezès matavimas) [25]. Hipertoninis druskos tirpalas ir naujieji vazopresino receptorių antagonistai yra efektyvūs gydant simptominę hiponatremiją [26]. Hiponatremija su galvos smegenų edema gali pasireikšti esant širdies nepakankamumui. Mūsų tirtam dilatacine kardiomiopatija sergančiam ligoniui dèl ženklios hiponatremijos ryškejjo galvos smegenų edemos klinika, nulèmusi letalinę baigtị.

Hiponatremija yra grịžtamos demencijos priežastis vyresnio amžiaus žmonèms. Yra keletas grižtamos demencijos būklių. Tarp jų - ED, ypač hiponatremija, kuri gali sąlygoti praeinančius kognityvinių funkcijų sutrikimus. Tirtas ryšys tarp kognityvinių sutrikimų ir serumo natrio koncentracijos vyresnio amžiaus žmonèms. Tirta 70 vyresnio amžiaus asmenų, 28 (40\%) jų nustatyta hiponatremija; 4 (5,7\% visos populiacijos) kognityvinès funkcijos buvo susilpnejjusios. Simptominiams ligoniams hiponatremija buvo sunki, jos pradžia greita. Vyresniems asmenims su greita demencijos simptomų pradžia yra svarbus serumo natrio koncentracijos nustatymas [27]. Mūsų tyrimo duomenimis, visiems demencija sergantiems ligoniams nustatyta hiponatremija - 125,5 $\pm 2,2 \mathrm{mmol} / \mathrm{l}$. Publikuotas pirmas įrodytas hipofosfatemijos sukeltos leukoencefalopatijos klinikinis atvejis: 61 metu moteriai kartojosi sąmonès pritemimo epizodai; MRT parode tilto ir blyškiojo kamuolio pažeidimą ir ekstensyvinę leukoencefalopatiją; nustatytas leukoencefalopatijos ryšys su hipofosfatemija. Nors hipofosfatemija sąlygoja pontininę ir ekstrapontininę mielinolizę, apie gilų baltosios smegenų medžiagos pažeidimą nebuvo skelbta. Atlikta smegenų biopsija atskleidè nespecifinę demielinizaciją su glioze, duomenys rodè lètinę osmozinę mielinolizę. Sunorminus fosfatų kiekị kraujo serume, sąmonès pritemimo epizodai nesikartojo, MRT pokyčiai išnyko. Hipofosfatemija gali sąlygoti leukoencefalopatiją, kurią galima koreguoti [28]. Klinikinis atvejis: 58 metų vyras, sergantis užleista stemplès karcinoma, sukèlusia užpakalinès grị̌tamos encefalopatijos sindromą (UGES). Klinika pasireiškè ryškiu sąmonès sutrikimu. Tyrimai atskleide hiperkalcemiją ir padidejusị parathormono peptido kieki (PTHrP). MRT hospitalizacijos dieną ir praejus 24 dienoms parodè grižtamus plačiai išplitusius baltosios medžiagos pokyčius, kurie nulèmė UGES diagnozę. Klinikinès ir radiologinès manifestacijos pagerejjo, sunorminus kalcio kiekị kraujo serume. Tai pirmas aprašytas hiperkalcemijos sukeltos UGES klinikinis atvejis, susijęs su PTHrP kiekio padidejimu [29]. Hiperkalcemijos sąlygoto UGES atveju gali pasireikšti vazogeninè edema [30].

Literatūroje pateikiami duomenys, kad ekstrapontininè 
mielinolizè susijusi su ED. Aprašytas striatum sindromas dèl hiponatremijos ir jos korekcijos 50 metų vyrui. Ekstrapontininès mielinolizès manifestacija patvirtinta MRT [31]. Pateiktas neramių kojų sindromo (NKS), sąlygoto pirminio hiperparatiroidizmo su hiperkalcemija, klinikinis atvejis: ligoniui pasireiškẻ NKS simptomai po paratiroidektomijos, kurie išnyko sunorminus parathormono ir kalcio kiekị kraujo serume [32].

25 metų marokietei pasireiškè tetanija. Prieš tris savaites moteriai buvo diarejja, o prieš kelias dienas jai pasireiškè rankų raumenų spazmai ir parestezijos. Tyrimai atskleide ryškų elektrolitų balanso sutrikimą [33]. Hipokalcemija gali būti epilepsia partialis continua priežastis [34]. 30 metų vyras, sergantis temporaline epilepsija, susijusia su hipokalcemija, sąlygota pirminio hipoparatiroidizmo. Jis sirgo epilepsija nuo 14 metu amžiaus, vèliau pasireiškè generalizuoti epilepsiniai priepuoliai. Pradžioje jie buvo kontroliuojami fenitoinu. Ligoniui taip pat nustatyta hipokalcemija dèl pirminio hipoparatiroidizmo. Epilepsinis židinys nustatytas temporalinejje skiltyje atliekant EEG, ir ji gali aktyvuoti hipokalcemija. Hipoparatiroidizmo kontrolè, valproinès rūgšties skyrimas, kalcio metabolizmo seka yra esminiai dalykai šiam ligoniui [36]. Epilepsinių priepuolių priežastis gali būti ir hiperkalcemija. Epilepsiniai priepuoliai yra susiję su kalcio karbonato pertekliumi. Klinikinis atvejis: ligoniui pasireiškè epilepsinè būklè dèl hiperkalcemijos. Ekskliuduota skydliaukès ir prieskydinių liaukų disfunkcija, piktybinis procesas, dauginè mieloma. Vertinta, kad hiperkalcemija atsirado dèl pieno šarmų sindromo ir ilgalaikio kalcio karbonato vartojimo [35]. Hiperkalcemiją gali sukelti diuretikų ar AKF inhibitorių vartojimas. Dviem mūsų tirtiems epilepsija sergantiems ligoniams nustatyta hipokalcemija (vienam jų diagnozuotas antrinis hipoparatiroidizmas), trečiam ligoniui buvo hiperkalcemija.

Migrena serga apie 14\% pasaulio populiacijos. Ne visi jos rizikos veiksniai yra žinomi. Kalcio kiekio padidejimas gali skatinti migreną [37]. Mūsų tyrimo duomenys tai patvirtino - visoms migrena sergančioms ligonėms nustatyta hiperkalcemija. Aprašyti židininiai neurologiniai simptomai hiperkalcemijos atveju. Ligonis skundèsi nuovargiu, depresija, troškuliu, gausiu šlapinimusi. Pasireiške židininiai neurologiniai simptomai: centrinès kilmès aklumas (amaurosis fugax), anomija, dešinès rankos dizestezija ir praeinantis smegenų išemijos priepuolis. Simptomai išnyko, kai serumo kalcio koncentracija sumažèjo nuo 13,2 iki 9,8 mg/100 ml [38].

Simptominès bradikardijos priežastys yra ịvairios: padidèjęs $n$. vagus tonusas, vaistų toksiškumas, ūmi miokardo išemija, širdies blokas ir ED. Hiperkalemija gali pasireikšti dèl ilgalaikio gydymo AKF inhibitoriais ar ARB. 87 metu moteriai, ilgą laiką vartojusiai ARB, pasireiškè bradikardija, kardiogeninè sinkopè ir staigios mirties rizika. Sinkopę sąlygojo jatrogeninè hiperkalemija [39]. Sinkopè ịvyko 7(6,9 proc.) mūsų tirtiems ligoniams: 6 (5,9 proc.) jų nustatyta hipokalemija (2 ligoniams buvo skiriami diuretikai), 1(1,0 proc.) - hiperkalemija. Ūminè vangi kvadriparezè, nulemta hiperkalemijos, yra reta ir rimta, bet grižtama būklè. 73 metų moteriai paraparezè dèl hiperkalemijos dešimties valandų laikotarpiu progresavo iki kvadriparezès. Sunorminus kalio kiekị kraujo serume, raumenų jèga atsistatè, ir ligonè pasveiko be komplikacijų [40]. 52 metų vyrui, sergančiam IFN, pasireiškej kvadriparezè ir dusulys. Nustatyta hiperkalemija (9 mmol/l). EKG rodè tipinius hiperkalemijos požymius. Gydant hiperkalemiją, po 30 minučių simptomai pagerejo, o po 5 valandu išnyko. Apžvelgti 62 straipsniai ir analizuoti 73 ligoniai, kuriems diagnozuotas antrinis hiperkaleminis paralyžius. Ligoniams pasireiškè kvadriparezė, kvėpavimo nepakankamumas, susilpnejjo refleksai ir išnyko jutimai. Beveik pusei visų ligonių kalio koncentracija kraujo serume buvo aukštesnè negu 9 mmol/l. Būklè pagerèjo 89\% ligonių. Hiperkalemija yra reta, bet koreguojama ūmaus vangaus paralyžiaus priežastis [41]. Sunki hipokalemija gali būti Guillain-Barre' sindromo priežastis. 41 metų vyrui su ryškia hipokalemija ir hipomag-nezemija pasireiške ūmi vangi kvadriparezė [42]. Dažniausiai hipokalemiją sukelia diuretikų vartojimas.

Miopatija yra reta idiopatinio hipoparatiroidizmo manifestacija. Pateiktas hipokalceminès miopatijos, sukeltos hipoparatiroidizmo, klinikinis atvejis: 48 metų vyrą šešerius metus vargino raumenu skausmas, buvo nustatytas padidèjęs kreatinkinazès kiekis kraujo serume. Laboratoriniai tyrimai atskleidè sumažèjusi kalcio kiekị kraujo serume, žemą-normalų parathormono kiekị, padidejusị fosforo kiekị ir normalų 25-hidroksi vitamino D kiekị. Ligoniui diagnozuotas idiopatinis hipoparatiroidizmas, jis gydytas kalciu ir kalcitrioliu. Stebètas ryškus klinikinis pagerejimas, susinormino kreatinkinazès kiekis. Diagnozuota hipoparatiroidinè miopatija. Atkreiptas dèmesys ị tai, kad ligoniams, kuriems pasireiškia neaiškios kilmès mialgijos ir/ar raumenų silpnumas, reikia nustatyti kalcio kiekị kraujo serume [43]. 49 metų vyrui pasireiškè rankų ir kojų raumenų silpnumas. Nustatyta hipokalemija. Diagnozuota hipokaleminė miopatija, skirti kalio preparatai. Simptomai regresavo. Pacientas vartojo labai daug žaliosios arbatos ekstrakto, simptomai pasireiškè per dvi savaites [44]. I tipo miotoninè distrofija yra autosominè-dominantinè liga, kuriai būdingas multisisteminis pažeidimas. Jos atveju gali būti raumeninis ir neraumeninis pažeidimas. Pasireiškia endokrininiai sutrikimai (lytinių liaukų, kasos ir antinksčių disfunkcija). Elektrolitų sutrikimai sergant I tipo miotonine distrofija yra reti. 42 metų korèjiečiui, sergančiam I tipo miotonine distrofija, nustatytas natrio 
ir kalio kiekio padidejjimas kraujo serume. Hipernatremija buvo dèl pirminès hipodipsijos, hiperkalemija vertinta kaip IFN pasekmè [45].

69 metų moteriai dèl hipofosfatemijos pasireiškè encefalopatija ir progresuojantis silpnumas [46]. Intraveninis gliukozės skyrimas yra dažniausia hospitalizuotų ligonių hipofosfatemijos priežastis. Daugumoje atvejų šios hipofosfatemijos yra asimptominès. Sunki hipofosfatemija, kombinuota su skysčiu kiekio organizme sumažèjimu, gali sukelti ūminę neuropatiją, imituojančią Guillain-Barre' sindromą. Blogai besimaitinančiam ligoniui buvo paskirtas intraveninis maitinimas be intraveniniu fosfatų. Nustatyta hipofosfatemija. Ligoniui pasireiškè ūminè sensomotorinè neuropatija. Intraveninis fosfatų skyrimas normalizavo neurologinius simptomus. Parenterinio maitinimo sąlygota hipofosfatemija gali būti hipofosfateminès neuropatijos priežastis [47]. Aprašytas ligonis, kuriam po cholecistektomijos pasireiškè kvadriparezè. Paralyžių tikriausiai sąlygojo stiprios hipofosfatemijos sukelta neuropatija, kurios simptomai pagerejo sunorminus fosforo koncentraciją kraujo serume [48].

Apibendrinant pateiktus duomenis, galima teigti, kad ED gali būti epilepsinių priepuolių, migrenos, kognityvinių sutrikimų, raumenų spazmų, galvos smegenų edemos priežastis arba gali pasireikšti sergant nervų ligomis. Žinant tai, svarbu laiku nustatyti elektrolitų koncentraciją kraujo serume ir koreguoti ligoniu gydymą.

\section{Išvados}

1. Kalio, natrio ir chloro balanso sutrikimai nustatyti sergant ir išeminiu, ir hemoraginiu insultu. Vyravo hipokalemija. Galvos smegenų infarkto atveju, palyginus su sergančiųjų lètine galvos smegenų išemija grupe, nustatytas statistiškai patikimas kalio koncentracijos kraujo serume sumažejimas.

2. Visiems Parkinsono liga sergantiems ligoniams nustatyti kalcio kiekio kraujo serume pokyčiai. Vyravo hipokalcemija.

3. Epilepsinių priepuolių priežastimi gali būti ir hipokalcemija, ir hiperkalcemija. Hiperkalcemija gali provokuoti migreną.

4. Kognityvinius sutrikimus nulèmè natrio kiekio pokyčiai. Visiems demencija sergantiems ligoniams nustatyta hiponatremija. Demencijos atveju, palyginus su sergančiujų lètine galvos smegenų išemija grupe, natrio koncentracijos sumažejjimas kraujo serume buvo statistiškai patikimas. Hiponatremija gali būti galvos smegenų edemos priežastis.

5. Galvos smegenų augliu sergantiems ligoniams buvo hipochloremija.

6. Sinkope gali ịvykti ir hipokalemijos, ir hiperkalemijos atveju. Hipokalemija gali būti parestezijų priežastis.

7. Raumenų spazmai pasireiškẻ esant hipokalcemijai ir hipomagnezemijai.

\section{Literatūra}

1. Samuels MA, Seifter JL. Encephalopathies caused by electrolyte disorders. Semin Neurol 2011;31(2):135-8.

https://doi.org/10.1055/s-0031-1277983

2. Murphy-Human T, Diringer MN. Sodium disturbances commonly encountered in the neurologic care unit. J Pharm Pract 2010;23(5):470-82.

https://doi.org/10.1177/0897190010372323

3. Jedras M, Ostrovski G. Hyponatremia. Wiad Lek 2013;66(4):27780.

4. Riggs JE. Neurologic manifestations of fluid and electrolyte disturbances. Neurol Clin 1989;7(3):509-23. https://doi.org/10.1016/S0733-8619(18)30797-7

5. Diringer M. Neurologic manifestations of major electrolyte abnormalities. Handb Clin Neurol 2017;141:705-713.

https://doi.org/10.1016/B978-0-444-63599-0.00038-7

6. Jansen A, Velkeniers B. Neurological involvement in a case of hypophosphatemia. Eur J Intern Med 2003;14(5):326-328. https://doi.org/10.1016/S0953-6205(03)00098-0

7. Siddiqui MF, Bertorini TE. Hypophosphatemia induced neuropathy: clinical and electrophysiological findings. Muscle Nerve 1998;21(5):650-2.

https://doi.org/10.1002/(SICI)1097-4598(199805)21:5<650::AIDMUS14>3.0.CO;2-Z

8. Espay AJ. Neurologic complications of electrolyte disturbances and acid base balance. Handb Clin Neurol 2014;119:365-82. https://doi.org/10.1016/B978-0-7020-4086-3.00023-0

9. Barri YM, Knochel JP. Hypercalcemia and electrolyte disturbances in malignancy. Hematol Oncol Clin North Am 1996;10(4):775-90.

https://doi.org/10.1016/S0889-8588(05)70367-1

10. Shibata H. Cancer and electrolytes imbalance. Gan To Kagaku Ryoho 2010;37(6):1006-10.

11. Alam MN, Uddin MJ, Rahman KM, Ahmed S, Akhter M, Nahar N. et al. Electrolyte changes in stroke. Mymensingh Med J 2012;21(4):594-9.

12. Kusuda K, Saku Y, Sadoshima S, Kozo I, Fujishima M. Disturbances of fluid and electrolyte balance in patients with acute stroke. Nihon Ronen Igakkai Zasshi 1989;26(3):223-7.

13. Rodrigues B, Staff I, Fortunato G, Mclullough LD. Hyponatremia in the prognosis of acute ischemic stroke. J Stroke Cerebrovasc Dis 2014;23(5):850-4.

https://doi.org/10.1016/j.jstrokecerebrovasdis.2013.07.011

14. Soiza RL, Cumming K, Clark AB, Bettencourt-Silva JH, Metcalf AK, Bowles KM. et al. Hyponatremia predicts mortality after stroke. Int J Stroke 2015;10(100):50-5. 
https://doi.org/10.1111/ijs.12564

15. Bei HZ, You SJ, Zheng D, Zhong CK, Du HP, Zhang Y. et al. Prognostic role of hypochloremia in acute ischemic stroke patients. Acta Neurol Scand 2017; 14:10.1111/12785.

16. Lebedev AA. Water electrolyte disorders in the acute period of a stroke. Zh Nevropatol Psichiatr Im SS Korsakova 1977;77(6):857-62.

17. Riha HM, Erdman MJ, Vandigo JE, Kimmons LA, Goyal N, Davidson KE. et al. Impact of moderate hyperchloremia on clinical outcomes in intracerebral hemorrhage patients treated with continuous infusion hypertonic saline: a pilot study. Crit Care Med 2017;45(9):947-953.

https://doi.org/10.1097/CCM.0000000000002522

18. Sadan O, Singbartl K, Kandiah PA, Martin KS, Samuels OB. Hyperchloremia is associated with acute kidney injury in patients with subarachnoidal hemorrhage. Crit Care Med 2017;45(8):1382-1388.

https://doi.org/10.1097/CCM.0000000000002497

19. Guo Z, Wang T, Zhang JH, Qin X. Clinical analysis of electrolyte imbalance in thalamic hemorrhage patients within $24 \mathrm{~h}$ after admission. Acta Neurochir Suppl 2011;111:343-8. https://doi.org/10.1007/978-3-7091-0693-8_57

20. Chen I, Mitchell P. Serum potassium and sodium levels after subarachnoidal haemorrhage. Br J Neurosurg 2016;30(5):554-9. https://doi.org/10.1080/02688697.2016.1181151

21. Gao F, Wang CT, Chen C, Guo X, Yang LH, Ma XC. et al. Effect of hypokalemia on functional outcome at 3 months post stroke among first ever acute ischemic stroke patients. Med Sci Monit 2017;10;23:2825-2832. https://doi.org/10.12659/MSM.902464

22. Ybanez N, Agrawal V, Tranmer BI, Gennari FJ. Severe hypokalemia in a patient with subarachnoidal hemorrhage. Am J Kidney Dis 2014;63(3):530-5. https://doi.org/10.1053/j.ajkd.2013.07.005

23. Adler C, Suarez V, Blomeyer R, Dohmen C, Bethe U, Burst $\mathrm{V}$. Rapid progress of a cerebral edema due to fulminant hyponatremia. Med Klin Intensivmed Notfmed 2017;24,10.1007/s 00063-017-0308-7.

24. Diringer MN, Zazulia AR. Hyponatremia in neurologic patients: consequences and approaches to treatment. Neurologist 2006;12(3):117-26. https://doi.org/10.1097/01.nrl.0000215741.01699.77

25. Overgaard-Steensen C, Ring T. A practical treatment of hyponatremia. Ugeskr Laeger 2012;9;174(15):1016-9.

26. Camterlain L. Hyponatremia caused by polydipsia. Crit Care Nurse 2012;32(3):e 11-20.

27. Pentimone F, Dei Corso L. Hyponatremia, cause of reversible dementia in the elderly. Minerva Psichiatr 1992;33(3):165-7.

28. Okazaki M, Hirano M, Iwatsu T, Yamana M, Suzuki H, Satou T. et al. Treatable leukoencephalopathy in a patient with hypophosphatemia. Case Rep Neurol 2017;3;8(3):264-271.
29. Nakajima N, Ueda M, Nagayama H, Yamazaki M, Katayama Y. Posterior reversible encephalopathy syndrome due to hypercalcemia associated with parathyroid hormone related peptide: a case report an review of the literature. Intern Med Med 2013;52(21):2465-8.

https://doi.org/10.2169/internalmedicine.52.0444

30. Kim JH, Kim MJ, Kang JK, Lee SA. Vasogenic edema in a case of hypercalcemia induced posterior reversible encephalopathy. Eur Neurol 2005;53(3):160-2.

https://doi.org/10.1159/000086127

31. Dickoff DJ, Raps M, Yahr MD. Striatal syndrome following hyponatremia and its rapid correction. A manifestation of extrapontine myelinolysis confirmed by magnetic resonance imaging. Arch Neurol 1988;45(1):112-4.

https://doi.org/10.1001/archneur.1988.00520250122033

32. Lim LL, Dinner D, Tham KW, Siraj E, Skields RJr. Restless legs syndrome associated with primary hyperparathyroidism. Sleep Med 2005;6(3):283-5.

https://doi.org/10.1016/j.sleep.2004.10.014

33. Pedrazzini B, Favrat B, Lehr HA, Bodenmann P A. Moroccan woman with severe electrolyte disorder. BMJ Case Rep 2010;3;2010.

https://doi.org/10.1136/bcr.08.2009.2188

34. Chhabra P, Modi M, Garg A, Prabhakar S, Bhadada SK. Hypocalcemia: a rare cause of epilepsia partialis continua. Neurol India 2019;60(4):432-3.

35. Kashouty R, Yono N, Al Samara M. Status epilepticus secondary to milk alkali syndrome induced by hypercalcemia (oral antacids). Seizure 2011;20(8):659-61. https://doi.org/10.1016/j.seizure.2011.03.011

36. Takeuchi H, Ikeda A, Otsuka Y, Saiki E, Shimohama S, Takahashi R. A case with temporal lobe epilepsy associated with hypocalcemia due to primary hypoparathyroidism. Rinsho Shinkeigaku 2006;46(7):510-2.

37. Yin P, Anttila V, Siewert KM, Palotie A, Davey Smith G, Voight BF. Serum calcium and risk of migraine: aMendelian randomization study. Hum Mol Genet 2017;15;26(4):820-828.

38. Longo DL, Witherspoon JM. Focal neurologic symptoms in hypercalcemia. Neurology 1980;30(2):200-1. https://doi.org/10.1212/WNL.30.2.200

39. Giancaspro G, Leppa M, Genuini I, Caselli S, Fedele F. Syncope caused by iatrogenic hyperkalemia. J Cardiovasc Med (Hagerstown) 2009;10(1):72-4. https://doi.org/10.2459/JCM.0b013e328319bfa4

40. Garg SK, Saxena S, Juneja D, Singh O, Kumar M, Mukherji JD. Hyperkalemia: a rare cause of acute flaccid a quadriparesis. Indian J Crit Care Med 2014; 18(1):46-8. https://doi.org/10.4103/0972-5229.125439

41. Panichpisal K, Gandhi S, Nugent K, Anziska Y. Acute quadriplegia from hyperkalemia: a case report and literature review. Neurologist 2010; 16(6):390-3. 
https://doi.org/10.1097/NRL.0b013e3181b120b8

42. Saroja AO, Naik KR, Khanpet MS, Uncommon dyselectrolytemia complicating Giullain-Barre' syndrome. J Neurosci Rural Pract 2013;4(3):328-30.

https://doi.org/10.4103/0976-3147.118794

43. Policepatil SM, Caplan RH, Dolan M. Hypocalcemic myopathy secondary to hypoparathyroidism. WMJ 2012;111(4):173-5.

44. Fukumoto M, Yamashiro N, Kobayashi F, Nagasaka T, Takiyama Y. A case of hypokalemic myopathy induced by excessive drinking of a beverage containing green tea extract. Rinsho Shinkeigaku 2013;53(3):239-42.

https://doi.org/10.5692/clinicalneurol.53.239

45. Ko WJ, Kim KY, Kim SM, Hong SJ, Lee SH, Song R. et al. A case of myotonic dystrophy with electrolyte imbalance. J Korean Med Sci 2013; 28(7):1111-3. https://doi.org/10.3346/jkms.2013.28.7.1111

46. Jansen A, Velkeniers B. Neurological involvement in a case of hypophosphatemia. Eur J Intern Med 2003;14(5):326-328. https://doi.org/10.1016/S0953-6205(03)00098-0

47. Iguchi Y, Mori K, Koike H, Mano K, Goto Y, Kato T. et al. Hypophosphataemic neuropathy during total parenteral nutrition. BMJ Case Rep 2009;pii: bcr.08.2008.0718.

48. Siddiqui MF, Bertorini TE. Hypophosphatemia induced neuropathy: clinical and electrophysiologic findings. Muscle Nerve 1998;21(5):650-2.

https://doi.org/10.1002/(SICI)1097-4598(199805)21:5<650::AIDMUS14>3.0.CO;2-Z

\section{ELECTROLYTE BALANCE DISORDERS AND NEUROLOGICAL PATHOLOGY L.Kimševaitė}

Key words: electrolyte imbalance, neurological pathology. Summary

Objective. To analyse neurological pathology in patients with electrolyte imbalance.

Materials and methods. We studied 101 patients with electrolyte balance disorders and neurological pathology at Vilnius City Clinical Hospital's Departments of Internal Diseases and of Nephrology in June 2017 - April 2018. The patients were aged from 31 to 99 years (mean $-75,0 \pm 1,3$ years), 68 of them were women, and 33 were men. The average duration of inpatient treatment was 10,5 days. For all patients, a complete blood count and biochemical analysis of blood were performed, serum electrolytes levels were measured, electrocardiogram, echoscopy of internal organs, in case of indications - cerebral (spinal) computed tomography, magnetic resonance imaging were performed. The differences in the average of statistical data have been assessed in compliance with the Stju- dent reliability criterion $t$. The differences found have been considered statistically reliable when $\mathrm{p}<0,05$.

Results. Neurological pathology was analysed in cases of electrolyte imbalance. Cerebrovascular disorders were manifested in $26(25,7 \%)$ patients, cerebral oedema - 1(1,0\%), dementia - 6(5,9\%), chronic cerebral ischemia - 17(16,8\%), brain tumours - 3(3,0\%), Parkinson's disease - 7(6,9\%), essential tremor - 2(2,0\%), epilepsy - 3(3,0\%), syncope $-7(6,9 \%)$, polyneuropathy - $10(9,9 \%)$, neuralgia - 5(5,0\%), muscle spasms - $9(8,9 \%)$, paresthesias - 2(2,0\%). Disorders of potassium, sodium and chloride balance were found in patients with both ischemic and haemorrhagic strokes. Hypokalaemia prevailed. In the case of a cerebral infarction, the serum potassium level was $3,28 \pm 0,2 \mathrm{mmol} / 1$, in the case of chronic cerebral ischemia - 4,81 $\pm 0,2 \mathrm{mmol} / \mathrm{l}(\mathrm{p}<0,001)$. The serum sodium level in patients with dementia was $125,5 \pm 2,2$ $\mathrm{mmol} / \mathrm{l}$, in the case of chronic cerebral ischemia - 138,76 $\pm 1,3$ $\mathrm{mmol} / \mathrm{l}(\mathrm{p}<0,001)$. The reduced serum chloride level of $93,83 \pm$ $3,1 \mathrm{mmol} / 1$ was found in patients with a brain tumour. Hypocalcaemia prevailed in patients with Parkinson's disease - 1,99 $\pm 0,1$ $\mathrm{mmol} / \mathrm{l}$. Both hypocalcaemia $(1,92 \mathrm{mmol} / \mathrm{l})$ and hypercalcaemia $(2,63 \mathrm{mmol} / \mathrm{l})$ were diagnosed in the case of epilepsy. The elevated serum calcium level of $2,66 \pm 0,1 \mathrm{mmol} / 1$ was found in all migraine patients. Both hypokalaemia $(3,09 \pm 0,2 \mathrm{mmol} / \mathrm{l})$ and hyperkalaemia $(5,80 \mathrm{mmol} / \mathrm{l})$ were observed in cases of syncope. Hypokalaemia of 3,14 mmol/1 was found in cases of paresthesias. In patients with muscle spasms the serum calcium level was 1,96 $\pm 0,1 \mathrm{mmol} / 1$, magnesium - 0,66 $\pm 0,01 \mathrm{mmol} / 1$.

Conclusions. Disorders of potassium, sodium and chloride balance were found in patients with both ischemic and haemorrhagic strokes. Hypokalaemia prevailed. A statistically reliable reduction in serum potassium levels was found in the case of a cerebral infarction compared with the group of patients with chronic cerebral ischemia. Changes in serum calcium levels were found in all patients with Parkinson's disease. Hypocalcaemia prevailed. Epileptic seizures can be caused by both hypocalcaemia and hypercalcaemia. Hypercalcaemia can provoke migraine. Changes in sodium levels led to cognitive impairment. Hyponatremia was found in all dementia patients. The reduction in serum sodium levels was statistically reliable in the case of dementia compared with the group of patients with chronic cerebral ischemia. Hyponatremia may be the cause of cerebral oedema. Patients with a brain tumour had hypochloraemia. Syncope can occur in the case of both hypokalcaemia and hyperkalaemia. Hypokalaemia may lead to paresthesias. Muscle spasms occurred when there were hypocalcaemia and hypomagnesaemia.

Correspondence to: liudmila.kimsevaite@gmail.com

Gauta 2018-09-25 